Зорица Витић

Универзитет у Београду

Филолошки факултет

zvitic@fil.bg.ac.rs

\section{Александар Костић}

Универзитет у Београду

Филозофски факултет

Лабораторија за експерименталну психологију

akostic@f.bg.ac.rs

\title{
СТАРЕ СРПСКЕ ПОВЕЉЕ И ПИСМА КАО ДЕО ЕЛЕКТРОНСКОГ КОРПУСА СРПСКОГ ЈЕЗИКА (ЛЕКСИЧКИ ОСВРТ)
}

Старе српске повеље и писма у издању Љубомира Стојановића, најпотпунија збирка дубровачких ћириличких докумената, део су електронског корпуса српског језика од XII до XVIII века. Језик којим су писане знатно је ближи народном, говорном језику тога времена.

Изразите разлике у ортографији, постојање бројних латинизама, италијанизама и турцизама, необичне реалије, као и разноврсна ономастика, чине овај подузорак корпуса важним сведоком дугог паралелног постојања али и међусобних утицаја двају сличних језика - књижевног српскословенског и мање формалног народног језика.

Кључне речи: Старе српске повеље и писма, Електронски корпус, српскословенски језик, народни језик, латинизми, италијанизми, турцизми

Старе српске повеље сматрају се једним од напоузданијих историјских извора. Премда настале по узору на византијске исправе, незаобилазне су у истраживањима привреде, развитка друштва, државних установа, али и историјске топографије и демографије (уп. Михаљчић 1999: 529-532).

Иако се објављују дуже од једног и по столећа, још увек не постоји јединствени корпус српских повеља. ${ }^{1}$ Најстарија збирка Франца Миклошича Monumenta Serbica (1858) садржи манастирске повеље, за-

1 Најновије обухватно издање ћириличких повеља и писама од 1186. до 1321. године: Мошин, Ћирковић, Синдик 2011. 
писе и натписе и ћириличке исправе владара и великаша Дубровнику (Михаљчић 1999: 531). Ђура Даничић користио је ово незаобилазно издање у свом Рјечнику из књижевних старина српских (1863-1864).

Уз Стојана Новаковића, који је систематично истраживао и објављивао споменике српског права (Законски споменици српских држава средюега века, 1912), Александра Соловјева (Одабрани споменици српског права, 1926) и Владимира Мошина (Грчке повелье српских влада$p a$, са А. Соловјевим, 1936), као издавач српских средњовековних повеља издваја се историчар и филолог Љубомир Стојановић. Овом осведоченом познаваоцу српског рукописног и епиграфског наслеђа, ${ }^{2}$ тадашњем секретару Српске краљевске академије, поверено је да припреми издање докумената Дубровачког архива који су се налазили у Бечу, а које је, према одредбама мировног уговора склопљеног у Сен Жермену 1919. године, Аустрија требало да преда Краљевини Срба, Хрвата и Словенаца. Документа су пренета у Београд 1920. године и једно време су ту и задржана (Михаљчић 1997: 30).

Издање Љубомира Стојановића Старе српске повеле и писма. Кюига прва, Дубровник и суседи юегови приређено је у два дела. Први део издат је у Сремским Карловцима и Београду као део посебних издања Српске краљевске академије 1929. године (619 аката), а други део се, након Стојановићеве смрти, појавио у саставу исте серије 1934. године. Издато је укупно 1096 аката, подељених по народима са којима су Дубровчани саобраћали (Дубровник и Срби, Дубровник и Бугари, Дубровник и Арбанаси, Дубровник и Турии, Дубровник и Мачари, Дубровник и Румуни, Дубровчани међу собом и Допуне Степана Куљбакина), а затим, у оквиру сваке од ових целина, по личностима (уп. Михаљчић 1997: 30-31).

У кратком уводу на почетку прве књиге ${ }^{3}$ Љ. Стојановић изнео је методолошке смернице за издавање ових аката, а затим и преглед публикација где су поједина акта већ била штампана. Примећујући да су и сама дотадашња издања повеља и писама постала „библиографиска реткост“, као и да већином више не одговарају потребама савремене науке, Стојановић формулише основно начело свог дипломатичког издања: штампани текст треба да, што је могуће верније, представља слику оригинала. Отуда су задржане све скраћенице и „надметнута“ слова, као и

2 Међу његовим ранијим издањима издвајале су се шестотомна збирка старих српских записа и натписа (1902-1926), као и каталог рукописних књига Народне библиотеке у Београду (1903).

3 Овде је најављена и трећа књига која ће садржати манастирске и црквене повеље. Њен скоро довршен рукопис није објављен и налази се у Архиву CAHУ, бр. 7935/LXIX (Трифуновић 1988: 93). 
оригинална интерпункција. Очигледне погрешке нису исправљане, већ су означаване знаком узвика у загради. У напоменама су донесена читања ранијих издавача само у случају где Љ. Стојановић није био потпуно сигуран у своје. Такође, ако се у више аката понавља исти текст, први је штампан у целини, а у напоменама су дате разлике осталих. Издавач истиче да је „све то чинио не толико текста, колико језика ради“ (уп. Стојановић 1929: V-VII). Заиста, и летимичан поглед на ово издање увериће читаоца у језичку и графијску разноврсност која се ретко среће у старим српским текстовима.

Овакав начин издавања био је узрок томе да су се, приликом лематизације грађе у другом подузорку корпуса српског језика од XII до XVIII века (први углавном сачињавају српска средњовековна житија), у електронском облику нашле десетине варијаната истих речи, понајвише у зависности од тога да ли су у питању скраћенице са титлом или са натписаним словима, да ли се полуглас, уколико га уопште има, пише словом или замењује пајерком, да ли се користе лигатуре и др. ${ }^{5}$ Слично је и са бројевима, којих је, због датирања докумената, изузетно много: најчешће су забележени словима са титлом, али постоје и заиста неслућене комбинације означавања цифара или делимичног исписивања целих бројева. Ипак, када се сви граматички анотирани облици подведу под исту одредницу, остаје траг о шароликом писању, али је сналажење у мноштву облика ипак сасвим олакшано.

Иако грађа из Старих српских повеља и писама (ПП) није још увек у потпуности лематизована, претрага у довршеном де̂лу фреквенцијског речника пружа занимљиве резултате. На шестини узорка издвојили смо неколике лексичке групе (називи феудалних обавеза, вулгарни латинизми и италијанизми, турцизми) и проверили да ли су те речи забележене у Даничићевом Рјечнику из книжевних старина српских. 6 Важно је напоменути да је Ђ. Даничић, осим из Monumenta serbica, ексцерпирао лексичку грађу и из других дотадашњих издања повеља, ${ }^{7}$ тако да се део

4 О софтверској апликацији за претрагу досад објављених осам фреквенцијских речника српских средњовековних текстова в. Костић, Витић 2015: 303-313.

5 О специфичностима анотације српскословенског језика и о различитим принципима у издавању деела која су граматички обрађена и лематизована у оквиру Електронског корпуса српског језика в. Витић, Костић 2015: 315-323.

6 Поред овог основног критеријума за избор речи, проверили смо њихово постојање и у Рјечнику JАЗУ (ARJ), Етимологијском рјечнику Петра Скока (Skok) и Етимолошком речнику српског језика (ЕР).

7 То су појединачна издања из Гласника Друштва српске словесности (X-XV) и Споменици српски у две књиге Меда Пуцића (Даничић I:VII-IX). 
лексичког фонда дубровачких ћириличких докумената већ нашао у Рјечнику. Познато је да се Даничић није користио поетским, литургијским, богословским и белетристичким српскословенским преводним текстовима (Трифуновић 1975: 621), већ је бирао наративне и административно-правне изворе - управо повеље и законодавна акта. Стога је интересантно барем делимично проверити у којој мери би лексика повеља и писама из издања Љ. Стојановића додатно обогатила речник старог српског језика.

\section{1. Називи феудалних обавеза}

И у манастирским повељама-даровницама називи феудалних обавеза спадају у народну, а не књишку лексику. У општој употреби су Аднь, данькь и поданькь „данак“, дєєтькь „дажбина у вредности десетога дела пољопривредних производа“, внрь „натурално или новчано давање цркви“, работа „радна обавеза зависних људи“, пєрпюь прен. „новчано давање“ (Савић 2017: 182). Све ове речи јављају се и у ПП, а постоји и посебан израз за годишњу надокнаду српским велможама за уступање дела приморја јужно и северно од Дубровника: могорншь/ могорнышь tributum, у латинским записима „magarisium“, уз Даничићеву напомену „свуда само онај што су га давали Дубровчани“ (Павловић 2004: 225). Овај трговачки арабизам (mahārig) ограничен је на руски у дубровачки језик и упућује на везе са арапским трговцима у словенским земљама (Skok I, 448-9; ARJ VI, 894).

Даровнице прописују још неке дажбине чији се називи нису нашли у Даничићевом Рјечнику: днмьннна „порез разрезиван по домаћинству - диму“, повозь „превожење пртљага или терета уопште (запрегама)“, воловєрьштнна „давање волова у војне сврхе“ (Савић 2017: 182). По истом принципу скована реч, хапакс вродовьштнна, јавља се у потврди султана Мехмеда II Дубровчанима (ПП II, 270). Код Даничића забележена је само врста царине вродова у истом значењу - „бродарина“.

\section{2. Вулгарни латинизми и италијанизми ${ }^{8}$}

Називи за реалије пореклом из грчког, али усвојени преко својих познолатинских варијаната, као и прави средњовековни латинизми и

8 За ову категорију речи коришћен је Диканжов речник вулгарног латинског (Ducange 1883-1887). 
италијанизми најчешћи су у списковима драгоцености поверених Дубровчанима на чување, тзв. покладницама, ${ }^{9}$ и у бројним сачуваним тестаментима. Многи су се нашли у Даничићевом Рјечнику, самим тим и у осталим речницима. То су старе мере, тканине, називи драгог камења, оружја, разноврсне посуде: ${ }^{10}$

акьсажа, акьсахь ехagium, „стара мера за племените метале и бисер“,

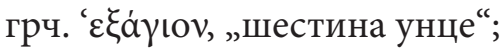

акьсаинть axamit, exametum, „врста свиле, одећа од такве тканине“,

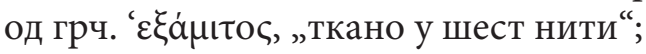

Балась, и деминутиви Баласеть, Баласннь balasius, „рубин светлије бoje“;

Бдлєстра (ПП I, 284) balestra, „лук и стрела“, „оружје које избацује разне пројектиле“; ${ }^{11}$

Бачниь baccile; Бокарь bocale, итал. boccale; Брокета, Бокета broca, brochata „мали врч“, „пехар за воду“; Боүцать bauca, „врста вазе“.

Један списак заоставштине из 1514. године (ПП II, 455) привлачи пажњу својим поднасловом: „ддвєнтарнш шдь пратєжн“. Састављач је свакако имао на уму инвентар ствари/робе (inventarium), али је сковао нешто другачију латинску реч. На овај погрешни латинизам Даничић није наишао, али бележи врєвєлєь (ПП II, 210), прилично деформисан облик речи privilegium.

Лат. habitus, забележено као „аьнть“, налази се у два тестамента из Стона из друге половине XV века (ПП II, 470, 471). У првом случају у питању је одећа намењена фратру духовнику, а у другом она спремљена за укоп. Ни ове речи, а ни глагола авдньцатн (итал. avanzare, Ducange 1883: t. 1, col. 462b, „унапредити, претицати“), који је чест у дубровачким тестаментима у значењу „претицати“ (ПП II, 468, 470, 473, 477), нема код Даничића, али их бележе остали речници („абит“ само ARJ I, 29, а „аванцати“ ARJ I, 122; EP, св. 1, 47).

У драматичној жалби Ђурице Петровића кнезу и судијама града Дубровника у којој износи да су га неки властелини апоставалн, сурово напали и готово убили 1401. године (ПП II, 418) нашао се познолатински

9 Покладница потврђује пријем оставе, поставе, похране или поклада и регулише начин његовог преузимања. Од познатијих породица као депоненти помињу се Бранковићи, Санковићи и Косаче, док као депозитар увек иступа Дубровник (Павловић 2004: 229).

10 Сви примери поменути су више пута у три оставе: војводе Сандаља (ПП I, 335), банице Анке и кћери јој Катарине (ПП I, 356) и херцега Стјепана Косаче (ПП II, 83). I, 164).

11 Даничић је нешто доцније исправио род ове именице у мушки - „балестар“ (ARJ 
глагол apostare, у једном од своја два основна значења: violare „насилно поступати, злостављати, вређати, окаљати“ (Ducange 1883: t. 1, col. 317c). Глагол апоставатн није забележен ни у једном речнику, чак ни у Стулијевом Rjecsosloxju slovinsko-italijansko-latinskom (1806).

Преписка Дубровчана и војводе Сандаља на више места укључује посебну врсту брода крнгєньтннь brigentinus (ПП I, 257. 258, 273, 274, 460), чији се назив није нашао у Рјечнику (ARJ I, 645; Skok I, 209). Такође нема ни речи варьв Брь barberius („барбијер“ АRJ I, 183; ЕР, св. 2, 195) иако je 1514. године у Новом Пазару забележено да је берберину Марку због лекарских услуга припало нешто новца од заоставштине (ПП II, 459).

Овом малом попису ваља додати и глагол вдньдєшкатн. Влат. и итал. bandire „узнемирити, оптуживати, оговарати, вређати“у корену је забележеног ваньтоватн. Етимологија речи band „осуда, глоба“"(Skok I, 72; ARJ I, 171; EP, св. 2, 166-167), карактеристичне за правне споменике XIII -XVI века, може се довести у везу са влат. bannum/bannus (франачки правни израз), а према италијанском презенту на -іsсо настала је варијанта Баньдєшкатн, која се јавља једанпут у ПП, II, 408, али и у Дунду Мароју. У четвртом ату, у трећој сцени, Помет јадикује над превртљивошћу Фортуне, јер га је Тудешко „бандешкао“ из куће (Držić 1979: 485). Помет је избачен из куће, а у писму се Дубровчани моле да емина Мехмед-бега „не бандешкају много“. И опет занимљив спој елемената српскословенског, средњовековног латинског, италијанског и ренесансног дубровачког говора.

\section{3. Турцизми ${ }^{12}$}

Даничић бележи многе турцизме (различите титуле и функције, називе месеци, реалије, бројна турска имена), али у повељама и писмима налазе се неки општепознати, као и неки ретки, који нису у Рјечнику:

амьварь ambar, anbar, hambar „магаза, складиште“ (ПП II, 319);

арьzь $\operatorname{arz}$ (ПП II, 366, 396, 399, 400) „излагање, представљање, подношење“ жалбе, молбе;

арьмагань аrmağan „дар, поклон“ (ПП II, 487);

арьшннь $\operatorname{arşin~„лакат,~стара~мера~за~дужину“~(ПП~II,~376,~455);~}$

ахтьнама ahdname „повеља“ (ПП II, 337, 398);

какнга bakî „остатак“ (ПП II, 333,342);

дєфьтерьдарь И тєфьтєрьдарь defterdar (ПП II, 354) „рачуновођа, министар финансија“, и придев дєфьтєрьдарьскы (ПП II, 395);

12 Сви примери потврђени су у Шкаљићевом речнику турцизама (Škaljić $1985^{5}$ ). 


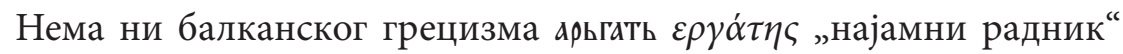
(ПП II, 309).

Необичне везе спајају две незабележене речи турског порекла из ПП са два српска средњовековна текста која такође нису била део грађе Даничићевог Рјечника:

Барьхань barrakān „део мушког или женског одела“ (ПП II, 476, 477);

Башахарь başalar „везир, угледни паша“ (ПП II, 354, 380, 382), и придев Башаларьскы (ПП II, 395).

У закону о рудницима деспота Стефана Лазаревића, издатом 1412. године, у члану XIII, под насловом $\omega$ ш'ндндарєхъ, стоје упутства да се „бархан женски шије по 16 динара, једнострук по 10, а бархан мушки са дугметима по 9“ (прев. према: Радојчић 1962: 54). Овај давно позајмљени турцизам иранског порекла у основи је речи „баршун“ (ЕР, св. 2, 218), „сомот“, толико значајне и распрострањене тканине да је њена продаја регулисана Будимским градским правом (Радојчић 1962: 73). Није необично да се општи назив материјала користи за именовање од њега сачињене одеће.

Напослетку, у завршном делу Јаничарових успомена Константина Михаиловића из Островице (крај XV века), сачуваних само у чешким и пољским преписима, у опису реда и поретка на турском двору (39. глава) чита се: „На двору турског цара и у читавом његовом савету постоје само два најистакнутија господина, који се о свему саветују, све уређују и наређују што год дође само на двор, а тиче се цара. Ту господу зову башалар ...“ (Михаиловић 1959: 93). Тако је у рукопису Смогулецких из XVI века (S), док у осталим рукописима уместо „башалар“ стоји „везирлер или пашалар“ (Михаиловић 1959: 57). У трима писмима упућеним Дубровчанима почетком XVI века реч „башалар“ такође означава високог турског достојанственика. Испоставља се да су се и у овом малом узорку нашла три никад незабележена турцизма: „ахтнама“, „бархан“ (као одевни предмет) и „башалар“.

Ваља нагласити још једну важну одлику повеља и писама, а то је обиље ономастичког материјала. Ови текстови прави су каталог дубровачких и српских властеоских породица, извор италијанских, турских, али и обичних народних имена. Даничић је многа од њих, из повеља које су му биле доступне, брижљиво уносио у свој Рјечник.

За разлику од дубровачких ћириличких исправа, манастирске даровнице показују наглашену диглосију (Павловић 2004: 226). У аренги, литерарном уводу, присутно је теолошки надахнуто казивање о чину да- 
ривања, док је сама диспозиција обликована нижим стилом, са бројним елементима народног језика. Иако би се језик манастирских повеља и даровница природније надовезивао на први подузорак корпуса, претежно сачињен од српске средњовековне житијне литературе, ${ }^{13}$ језик дубровачких повеља и писама, ${ }^{14}$ једноставан, свакодневни, са разноврсним лексичким новинама и морфологијом и синтаксом сасвим блиском народној употреби, чини својеврсну спону између старог и савременог језика и, као такав, омогућава сагледавање српског језика као целине. Свакако је управо зато као грађа за дијахрони анотирани корпус српског језика од XII века до савременог језика искоришћено издање Љ. Стојановића.

Досад испитани део узорка језика старих српских повеља и писама само наговештава правце будућих истраживања, али тек ће лематизацијом целокупне ове грађе, доступне у електронском облику, бити омогућен потпунији увид у њену разноврсност, те у специфичности које овај део корпуса чине незаобилазном допуном српскословенског лексичког фонда Даничићевог Рјечника.

\section{Извори и литература}

Витић, Зорица и Александар Костић. „Специфични захтеви анотације српскословенског у оквиру Електронског корпуса српског језика.“ Дигиталне библиотеке и дигитални архиви. А. Вранеш, Љ. Марковић (ур.). Београд: Филолошки факултет, 2015. 315-323. Штампано.

Даничић, Ђура. Рјечник из књижевних старина српских (I, 1863; II, 1863; III, 1864). Репр. Београд: Вук Караџић 1975. Штампано.

Du Cange, Charles du Fresne et al., Glossarium mediae et infimae latinitatis, éd. augm., Niort: L. Favre, 1883-1887. http://ducange.enc.sorbonne.fr/. Цитирано 16. 04. 2019.

Dimitrijević, Nataša i Mateo Žagar. „Najstarije štokavske inovacije u glagolskoj morfologiji ćiriličkih isprava dubrovačkog arhiva." Rasprave. Časopis Instituta za hrvatski jezik i jezikoslovlje, vol. 41, br. 2 (2015): 263-283. https://hrcak.srce.hr/150036. Цитирано 03. 06. 2019.

Držić, Marin. Djela, prir. F. Čale, Zagreb: Sveučilišna naklada Liber, 1979. Штампано.

Етимолошки речник српског језика. Ур. Александар Лома. Св. 1 (А-АШ), Београд: САНУ, 2003; Св. 2 (БА-БД), 2006; Св. 3 (БЕ-БЈ), 2008. Штампано.

13 Објављено је осам томова фреквенцијског речника старог српског језика начињених претежно на основу житијних текстова (Службени гласник 2009-2012). У корпус су укључена сва оригинална српска житија од XIII до XVII века, изузев Теодосијевог Житија св. Петра Коришког и Константиновог Житија деспота Стефана.

14 О најстаријим штокавским иновацијама у глаголској морфологији повеља и писама в. Dimitrijević, Žagar 2015: 163-283. 
Костић, Александар и Зорица Витић. „Софтверска апликација за претрагу и анализу српских средњовековних текстова.“ Дигиталне библиотеке и дигитални архиви. А. Вранеш, Љ. Марковић (ур.). Београд: Филолошки факултет, 2015. 303-313. Штампано.

Михаљчић, Раде. „Старе српске повеље и писма (издање Љ. Стојановића)“, Енииклопедија српске историографије, прир. С. Ћирковић и Р. Михаљчић, Београд: Knowledge, 1997, 30-31. Штампано.

Михаиловић, Константин, из Островице. Јаничарове успомене или Турска хроника. Предговор, превод и напомене Ђорђа Живановића, Споменик CAH, CVII, 1959. Штампано.

Михаљчић, Раде. „Повеље“, Лексикон српског среднег века, прир. С. Ћирковић и Р. Михаљчић, Београд: Knowledge 1999, 529-532. Штампано.

Мошин, Владимир, Сима Ћирковић и Душан Синдик (прир.), Зборник средюовековних ћириличких повеља и писама Србије, Босне и Дубровника, I (1186-1321). Београд: Историјски институт, 2011. Штампано.

Павловић, Слободан. „Жанрови старосрпског пословног стила.“ Научни састанак слависта у Вукове дане, 32/1 (2004): 223-234. Штампано.

Rječnik hrvatskoga ili srpskoga jezika, I-XXIII. Zagreb: JAZU, 1880-1976. Штампано.

Радојчић, Никола (изд.), Закон о рудницима деспота Стефана Лазаревића. Београд: Научно дело, 1962. Штампано.

Савић, Виктор. „Манастирске даровнице у српскословенском лексичком корпусу.“ Filologija, br. 68 (2017): 171-191. https://doi.org/10.21857/mnlqgc0v0y. Цитирано 10. 04. 2019.

Skok, Petar. Etimologijski rječnik hrvatskoga ili srpskoga jezika, knj. I. Zagreb: JAZU, 1971. Штампано.

Стојановић, Љубомир (прир.). Старе српске повеље и писма. Кюига І. Дубровник и суседи юегови. Први део, Београд- Ср. Карловци: СКА, 1929; Други део, Београд-Ср. Карловци: СКА, 1934. Штампано.

Stulli, Joakim. Rjecsoslòxje slovinsko-italijansko-latinsko. Dubrovnik 1806. Штампано.

Трифуновић, Ђорђе. „О Даничићевом Рјечнику из књижевних старина српских.“ Даничић III, Репр. Београд: Вук Караџић, 1975. 619-646. Штампано.

Трифуновић, Ђорђе. „Едициона пракса Љубомира Стојановића.“ Зборник Матище српске за славистику, 35 (1988): 83-95. Штампано.

Škaljić, Abdulah. Turcizmi u srpskohrvatskom jeziku. Sarajevo: Svjetlost, 19855. Штампано. 


\title{
Zorica Vitić
}

Faculty of Philology, University of Belgrade

akostic@f.bg.ac.rs

\section{Aleksandar Kostić}

Laboratory for Experimental Psychology

Faculuty of Philosophy, University of Belgrade

zvitic@fil.bg.ac.rs

\section{THE OLD SERBIAN CHARTS AND LETTERS WITHIN ELECTRONIC CORPUS OF SERBIAN LANGUAGE (A LEXICAL SURVEY)}

\begin{abstract}
Summary
The old Serbian charts and letters encompass written documents that span five centuries of Serbian history. They include vast official and private correspondence, important charts of Serbian kings and noblemen, as well as contracts and other administrative documents and could be treated as valuable and reliable historical source. Unlike the solemn lives of Serbian saints, the language in which they were written is much closer to spoken (vernacular) Serbian language of that period. The old charts and letters were collected and edited at the beginning of the 20th century in their original form by Ljubomir Stojanović, one of the most prominent Serbian philologists. The material in the Corpus is based on those editions.

Distinct orthographical variety, existence of numerous latinisms, italianisms and turcisms, unusual realia, as well as inestimable collection of onomastics make this sub sample an important witness of a long-lasting parallel existence and interaction of two similar languages - highly codified Serbian-Slavonic and much more informal common language. This material could be considered as a link between the old and the contemporary language, therefore it provides continuity in cognition of the whole of Serbian language.
\end{abstract}

Key words: THE OLD SERBIAN CHARTS AND LETTERS, ELECTRONIC CORPUS, SERBIAN-SLAVONIC, COMMON LANGUAGE, LATINISMS, ITALIANISMS, TURCISMS 